\title{
Erratum: Sanofi Aventis grooms its ranks for biotech partnering
}

Nuala Moran

Nat. Biotechnol. 27, 581-582 (2009); published online 8 July 2009; corrected after print 8 October 2009

In the version of this article initially published, the writer incorrectly states that "BiPar was spun out of Genentech to develop small-molecule inhibitors...." The text should have read "BiPar was set up to develop small-molecule inhibitors...." The error has been corrected in the HTML and PDF versions of the article.

\section{Erratum: Diagnostics firms face new patent claim worries}

Malorye Allison

Nat. Biotechnol. 27, 586-587 (2009); published online 8 July 2009; corrected after print 8 October 2009

In the version of this article initially published, on page 587, left column, last paragraph, it states incorrectly that GeneDX holds a patent to certain mutations in the connexin 26 gene related to keratitis-ichthyosis-deafness syndrome. GeneDX does not own that patent. The error has been corrected in the HTML and PDF versions of the article.

\section{Erratum: Novo awaits green light for diabetes drug}

Mike May

Nat. Biotechnol. 27, 682-685 (2009); published online 7 August 2009; corrected after print 8 October 2009

In the version of this article initially published, GLP-1 was incorrectly described as "glucose-lowering peptide-1"; the correct definition is "glucagonlike peptide-1." The article also stated incorrectly that Amylin and Lilly "filed a new drug application for this drug in July...” referring to Exenatide Once Weekly. This should be corrected to "their new drug application was accepted for review by the FDA in July....” The error has been corrected in the HTML and PDF versions of the article. 